\title{
Освітні вектори у сфері видавничої справи та редагування
}

\author{
Підмогильна Н.В., Терханова О.В.
}

\author{
Дніпровський національний університет імені Олеся Гончара
}

У статті здійснено спробу проаналізувати організацію та результати проведення навчальної практики, що $€$ важливою складовою у процесі підготовки майбутніх фахівців із видавничої справи та редагування, для студентів, які навчаються за першим (бакалаврським) рівнем вищої освіти. Європейська спрямованість освіти в Україні передбачає не лише приведення до єдиного стандарту освітніх програм, а й належну професійну підготовку спеціалістів, які могли б згодом реалізувати набуті знання та навички у будь-якій європейській країні. Попри існуючі відмінності в технічному оснащенні видавничих підприємств у Європі та в Україні, особливо розташованих в провінції, $є$ певний комплекс знань та умінь, які дозволять майбутнім фахівцям у сфері видавничої справи адаптуватися до новітнього друкарського устаткування, зреалізувати набуті навички у подальшій практичній роботі.

Викладачі, які працюють на факультеті систем і засобів масової комунікації Дніпровського національного університету імені Олеся Гончара, докладають чималі зусилля для того, щоб подати студентам об'ємні знання як про історію соціальних комунікацій - причому не лише в межах української парадигми, а й світової, - так і про сучасні тенденції розвитку засобів масмедіа, включаючи всі їхні форми та виявлення.

У фокусі уваги викладачів знаходиться і такий важливий елемент освітнього процесу, як практика студентів, яку можна визначити як одну з форм або один із методів навчання, орієнтованих не лише на засвоєння певної суми знань, а й на здобуття відповідних умінь та навичок. Саме питання організації та результатів практичної підготовки майбутніх спеціалістів ми спробуємо актуалізувати у пропонованій роботі. Як приклад реалізації навчально-методичних пошуків в організації навчального процесу та заохочення студентів до самостійної роботи у царині видавничої справи, їі історії та розвитку в Україні розглядається бібліографічний словник-довідник “Видавнича справа Придніпров'я в іменах: історія та сучасність», укладений викладачами факультету разом зі студентами за результатами проходження навчальної практики.

Зазвичай знання з історії видавничої справи студенти одержують в університетських аудиторіях та студіюючи відповідні вишівські підручники, але зміст підручників формує загальне уявлення про розвиток видавництв та друкарень на різних історичних етапах, і ці знання залишаються у теоретичному підґрунті професії, тобто інформацією зі спеціальної навчальної літератури. Зовсім інша справа, коли студенти збирають матеріали з історії видавництв, видань та видавців, яка стосується того регіону, в якому вони живуть. Власноручно зібрана та впорядкована інформація міцно закарбовується у пам'яті, а також суттєво розширює уявлення про культурні та історичні процеси, що відбувалися в одній з українських культурних провінцій на Придніпров'ї.

Ключові слова: видавнича справа та редагування; освітній процес; навчальна практика; самостійна робота студентів; видання; «Видавнича справа Придніпров'я в іменах: історія та сучасність».

\section{1. Вступ}

Постановка проблеми. Сьогодні галузь знань «Журналістика» включає кілька спеціальностей, які раніше були самостійними напрямками, а саме: власне «Журналістика», «Видавнича справа та редагування», «Реклама та зв'язки з громадськістю». Зрозуміло, що навчання за освітньо-професійними програмами

Pidmohylna N., Doctor of Philological Sciences, Professor, Head of the Department of Publishing and Intercultural Communication,

e-mail address: natvpodm@gmail.com, tel.: +3805637331233

ORCID: https://orcid.org/0000-0002-4044-981X, Oles Honchar Dnipro National University, 72, Gagarina Av., Dnipro, 49050, Ukraine Terhanova O., Candidate of Philological Sciences (Ph. D.), Associate Professor, Associate Professor of the Department of Publishing and Intercultural Communication, e-mail address: terkhanova_o@fszmk.dnulive.dp.ua. tel.: +3805637331233,

ORCID: https://orcid.org/0000-0003-0888-4894,

Oles Honchar Dnipro National University,

13, Naykova Str., Dnipro, 49050, Ukraine перерахованих спеціальностей передбачає певні особливості та набір навчальних дисциплін, які сприятимуть формуванню максимально глибокого й панорамного уявлення про майбутню професію, ї̈ сучасні тенденції та перспективи подальшого розвитку.

Викладачі, які працюють на факультеті систем і засобів масової комунікації Дніпровського національного
Підмогильна Н. В., доктор філологічних наук, професор, завідувач кафедри видавничої справи та міжкультурної комунікації, електронна адреса: natvpodm@gmail.com, тел.: +3805637331233,

ORCID: https://orcid.org/0000-0002-4044-981X, Дніпровський національний університет імені Олеся Гончара, пр. Гагаріна, 72, Дніпро, 49050, Україна

Терханова О. В., кандидат філологічних наук, доцент, дочент кафедри видавничоі справи та міжкультурної комунікації, електронна адреса: terkhanova_o@fszmk.dnulive.dp.ua тел.: +3805637331233,

ORCID: https://orcid.org/0000-0003-0888-4894, Дніпровський національний університет імені Олеся Гончара, вул. Наукова 13, Дніпро, 49050, Україна 
університету імені Олеся Гончара, докладають чималі зусилля для того, щоб подати студентам об'ємні знання як про історію соціальних комунікацій - причому не лише в межах української парадигми, а й світової, - так і про сучасні тенденції розвитку засобів мас-медіа, включаючи всі їх форми та виявлення.

У фокусі уваги викладачів знаходиться і такий важливий елемент освітнього процесу, як практика студентів, яку можна визначити як одну з форм або один із методів навчання, орієнтованих не лише на засвоєння певної суми знань, а й на здобуття відповідних умінь та навичок. Саме питання організації та результатів практичної підготовки майбутніх спеціалістів ми спробуємо актуалізувати у пропонованій роботі.

Аналіз останніх досліджень та публікацій. Останнім часом дослідники дедалі частіше звертаються до методичних проблем викладання в українській вищій школі, зосереджуючи увагу на таких актуальних питаннях, як упровадження інновацій у галузі вищої освіти [1; 2], кредитно-модульна система навчання [3; 4], а також на загальних тенденціях у підготовці фахівців з вищою освітою [5-9]. Значно рідше звертаються дослідники до питань організації та проведення практики у вищих навчальних закладах [10].

3-поміж численних - по-своєму цікавих і, безумовно, корисних - наукових та навчально-методичних розробок, пов'язаних із проблемами розвитку видавничої справи та редагування у світі (див., напр.: [11-16]), хочемо виокремити навчальний посібник викладачки Національного технічного університету України «Київський політехнічний інститут імені Ігоря Сікорського» І.Казак, в якому акцент зроблено на концептуальних напрямах розвитку вищої школи в Україні [17]. Попри спрямованість згаданого видання на підготовку фахівців технічних спеціальностей, вважаємо його зміст не лише важливим, а й таким, що може бути поширений на будьякі гуманітарні спеціальності. Дослідниця підкреслює, що підписана 29 європейськими країнами Болонська конвенція зобов'язує європейські виші привести освітні системи у відповідність до єдиного стандарту. Особливу значимість та актуальність для нашої розвідки становить слушна думка про наявність недоліків у підготовці спеціалістів в Україні, що зумовлені «внутрішньою зацикленістю національної системи освіти, оскільки вона не пов'язана з виробництвом, не може готувати спеціалістів для практичної роботи» $[17$, с. 7]. Цілком погоджуємося і з тезою щодо спрямування освітнього процесу на кінцевий результат, який забезпечував би застосування і використання набутих знань у будь-якій європейській країні [17, с. 7].

Отже, мова йде про практичну підготовку професіоналів у певній галузі. Зрозуміло, що технічній рівень вітчизняних видавництв, типографій та друкарень, особливо провінційних, подеколи важко порівняти з аналогічними установами та підприємствами європейських держав, оснащених найсучаснішим устаткуванням. Але, говорячи про такий вузький напрямок, як видавнича справа та редагування, слід розуміти, що володіння основними професійними навичками дозволить без особливих ускладнень адаптуватися до роботи з технічними засобами нового покоління.
Деякі науковці справедливо вважають, що вживання таких понять, як «вміння» та «навички» як синонімів, призводить до розмивання їх теоретичного визначення i втрати семантичного нюансування тих моментів, які сьогодні $€$ обов'язковими складниками будь-якої освітньої програми або робочої програми окремої навчальної дисципліни.

Якщо узагальнити думки та спостереження фахових методистів та дослідників, які вивчали теоретичний бік проблеми щодо смислового наповнення широко вживаних у практиці вищої школи понять, то можна зробити висновок: уміння включає здатність виконувати якісь дії і супроводжується процесом мислення [18, с. 10], тобто оцінки, раціонального вибору прийомів, спрямованих на оперативну й адекватну реалізацію цих дій; у понятті «навичка» виконанню дії передує досвід, надбаний внаслідок багаторазового її повторення [19], тобто на перший план висувається така характеристика, як автоматизм, так би мовити, внутрішня запрограмованість.

Мета статті полягає в тому, щоб оприлюднити новітні форми організації освітнього процесу, зокрема такої важливої її складової, як навчальна практика, і поділитися 3 колегами з вищих навчальних закладів України власним досвідом і здобутками, що може стати поштовхом до серйозного й цікавого обговорення актуальних і складних питань щодо цілеспрямованої підготовки майбутніх фахівців у галузі видавничої справи та редагування.

Об'єкт дослідження - бібліографічний словник-довідник «Видавнича справа Придніпров'я в іменах: історія та сучасність» [20] (див. рис. 1).

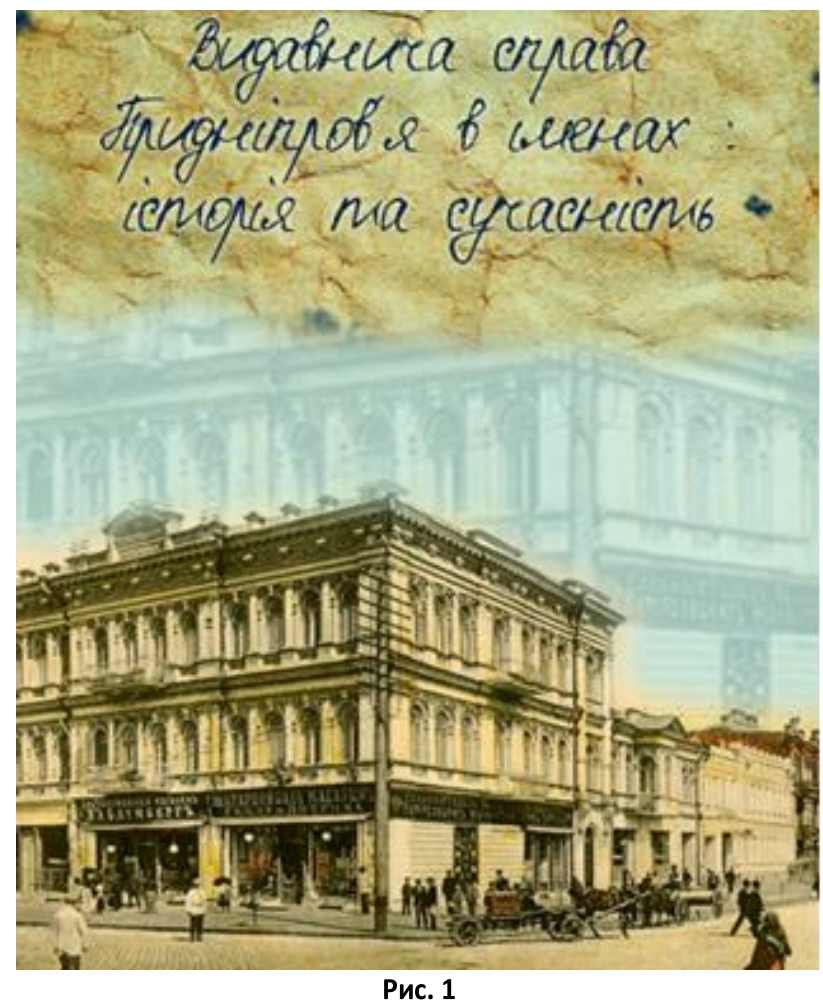

Методи дослідження. Під час роботи над статтею використано традиційні загальнонаукові методи спостереження, аналізу, синтезу та узагальнення, які застосовано при аналізі названого вище видання та викладу матеріалу щодо його підготовки до публікації. Спостереження застосовано як емпіричний метод на попередньому етапі 
вивчення об'єкта дослідження, причому здійснювалося як польове й суцільне спостереження об'єкта 3 метою формування неупередженого враження від нього. 3-поміж традиційних методів наукового дослідження обрано як найбільш ефективні - аналіз, у ході застосування якого об'єкт піддано розщепленню на окремі складові, тобто в нашому випадку - на окремі словникові статті, без чого розмова про контент словника-довідника взагалі була 6 беззмістовною, а також синтезу - методу, що має цілком протилежну аналізові спрямованість, оскільки, лише об'єднавши зафіксовані дані про словник, можемо утворити певну цілісність досліджуваного об'єкта. Доцільність застосування методу історіографічного пошуку в гуманітарній сфері зрозуміла особливо з урахуванням полісемантичності самої назви методу: в нашій розвідці значущість і привабливість цього методу зумовлена необхідністю формування уявлення про конкретні історичні етапи розвитку видавничої справи, такого уявлення, що не претендує на вичерпність, але, не заповнивши в такий спосіб «білі плями» на істориковидавничій мапі, неможливо говорити про історію видавництв ані в окремо взятому регіоні, ані загалом. Крім того, історіографічний пошук застосовано як допоміжний спосіб збору професійно орієнтованої літератури і джерел. Експериментальні прийоми унаочнені у процесі викладу матеріалу, оскільки і саме видання розглядається як експеримент в освітньому процесі, який не лише може бути продовженим на наступних етапах проходження аналогічної практики іншими студентами, а й повтореним в інших українських вишах. Також застосовано метод соціологічного дослідження - соціологічне опитування - з метою з'ясувати зацікавленість студентів названим виданням: пріоритет віддано безпосередньому опитуванню респондентів із традиційною в таких випадках метою - для збору первинної інформації про досліджуваний об'єкт та вимірювання громадської думки щодо поставленого питання. Визнавши оптимальним джерелом одержання інформації про проблему, що вивчається, студентську аудиторію, оскільки йдеться про урізноманітнення форм самостійної роботи учнівської молоді, зокрема організацію й проведення навчальної практики, а також вважаючи вербальну інформацію точнішою й оперативнішою, проведено зустрічпрезентацію словника-довідника «Видавнича справа Придніпров'я в іменах: історія та сучасність» у студентському середовищі 3 подальшим обговоренням названого видавничого проєкту.

\section{2. Результати дослідження}

У результаті здійсненого дослідження ми дозволимо собі висловити припущення, що пошуки нових форм проходження студентами, які навчаються за спеціальністю «Видавнича справа та редагування» галузі знань «Журналістика», навчальної практики та підготовки звітів про неї не повинні припинятися. Такий безперервний пошук стимулюватиме процес наповнення новим змістом вже звичних традиційних форм навчання і, сподіваємося, осучаснить та надасть свіжості таким складовим освітнього процесу, як самостійна робота студентів, професійна підготовка і навчальна практика.

\section{3. Обговорення}

Не ставлячи собі за мету широке висвітлення освітнього процесу в межах спеціальності «Видавнича справа та редагування», хочемо приділити увагу такій важливій ланці підготовки майбутніх фахівців, як навчальна практика. Як правило, навчальну практику студенти названої спеціальності проходять наприкінці другого та третього курсів, і програми цих практик зорієнтовані на те, щоб студенти відвідали підприємства й установи видавничої сфери - друкарні, редакційно-видавничі відділи різних установ, видавництва, аби на власні очі побачити специфіку роботи редакторів та видавців і подивитись, як народжується поліграфічний продукт, радіо- або телепрограма, майбутня книжка.

На жаль, сучасні економічні умови важко назвати сприятливими для активного й динамічного розвитку видавничої справи, і це в свою чергу позначається на загальному рівні культури, оскільки друкована продукція давно стала невід'ємною частиною загальної культурної палітри держави. 3 іншого боку, людина, яка перестає читати, не відчуває потреби у газетах та журналах, гальмує свій інтелектуальний розвиток, випадає на маргінеси суспільного й культурного життя.

Як привернути увагу до спеціальності, як заохотити молодь до навчання, як зробити привабливою професію, яку опановуєш? Ці питання колектив кафедри видавничої справи та міжкультурної комунікації, яка $є$ випусковою для спеціальності «Видавнича справа та редагування», ставить перед собою щодня. Одним із суттєвих, на нашу думку, чинників у засвоєнні спеціальних знань і набутті необхідних професійних навичок під час навчання $є$ практика - ті кілька тижнів, коли студенти безпосередньо спілкуються зі своїми майбутніми колегами, дізнаються від них про тонкощі й труднощі тієї справи, якій вони присвятили себе. Здавалося б, дуже просто й легко організувати й провести період практичної підготовки студентів, але ми прагнемо зробити цей час цікавим та корисним у професійному плані. Однією зі знахідок на цьому шляху вважаємо спроби, сказати б, матеріалізувати звіти з практики, виводячи традиційні щоденники практиканта на інший - вищий - щабель профпідготовки.

Ілюстрацією такого підходу може служити видання, підготовлене студентами-практикантами «Видавнича справа Придніпров'я: історія та сучасність». Зазвичай знання 3 історії видавничої справи студенти одержують в університетських аудиторіях та студіюючи відповідні вишівські підручники (див., напр.: [22-23]). Але зміст підручників формує загальне уявлення про розвиток видавництв та друкарень на різних історичних етапах, і ці знання залишаються, так би мовити, у теоретичному підґрунті професії, тобто інформацією зі спеціальної навчальної літератури. Зовсім інша справа, коли студенти збирають матеріали з історії видавництв, видань та видавців, яка стосується того регіону, в якому ми живемо. Власноручно зібрана та впорядкована інформація міцно закарбовується у пам'яті, а також суттєво розширює уявлення про культурні та 
історичні процеси, що відбувалися в одній зі значущих українських культурних провінцій - на Придніпров'ї.

Видання, про яке йдеться, являє собою бібліографічний словник-довідник, що зручно використовувати в навчальному процесі і просто як додаткове довідкове джерело у повсякденному житті. Подібні видання, звісно, існують (див., напр.: [24]), але орієнтовані на звужену аудиторію спеціалістів.

Багато хто зі студентів чи не вперше дізнався про те, що життя та діяльність таких визначних особистостей в українській історії та культурі, як Дмитро Іванович Яворницький, Іван Михайлович Труба, Кузьма Єрмолайович Котов та інших, пов'язані з нашим містом.

Бібліографічний словник-довідник за матеріалами, зібраними студентами, уклали доценти кафедри видавничої справи та міжкультурної комунікації ДнУ ім. О. Гончара Л.В.Куценко і О.В. Терханова. На зворотному боці палітурки читаємо: «Офіційна історія міста розпочалась у 1776 р., коли російська імператриця Катерина II вирішила будувати “Південну Пальміру”, порівнюючи їі зі столицею Російської імперії Санкт-Петербургом - Північною Пальмірою», - в такий спосіб підкреслено географічні координати регіону, про розвиток видавничої справи в якому йдеться у довіднику. Побудований довідник за алфавітним принципом, тобто ним зручно і просто користуватися. До деяких словникових статей було знайдено окремі відомості, і джерела, з яких їх взято, зазначені наприкінці статей, хоча в окремих випадках інформація історичного характеру про час створення видавництва чи організацію видання - це, власне, і все, що вдалося знайти. У другому випадку нам здається важливим вже те, що певний артефакт чи друкарню, яка існувала на теренах Придніпров'я, було згадано, і це може стати потужним імпульсом до подальших пошуків.

Розпорошені по різних виданнях та джерелах згадки про добре відомих або навіть мало відомих пересічним громадянам України діячів науки та культури структуровані за правилами укладання енциклопедій: тобто наводяться дані про життя та походження тієї чи іншої людини, її освіту, долю, участь у культурному житті Придніпров'я та України. Майже до всіх статей довідника, присвячених видавцям та науковцям, вдалося відшукати їхні портретні зображення або фотографії, що не лише прикрашають видання в цілому, а й зроблять для наступних поколінь студентів ці обличчя впізнаваними. Коли мовиться про якусь друкарню чи видання, то довідникова стаття супроводжується сканованими чи сфотографованими зображеннями титульних сторінок відповідних видань або того місця, того будинку у Дніпрі, де колись розташовувалася друкарня.

Особливу значущість, на нашу думку, мають статті, присвячені окремим діячам та виданням, що виходили в Україні та на Придніпров'ї на початку XX ст., у революційні часи та у післяжовтневий період існування Української держави.

Наприклад, життя і діяльність видатного українського видавця, літератора, політичного діяча Івана Труби (див. рис. 2) тісно пов'язані з Дніпром (Катеринославом). Активний учасник товариства «Просвіта» І. Труба брав

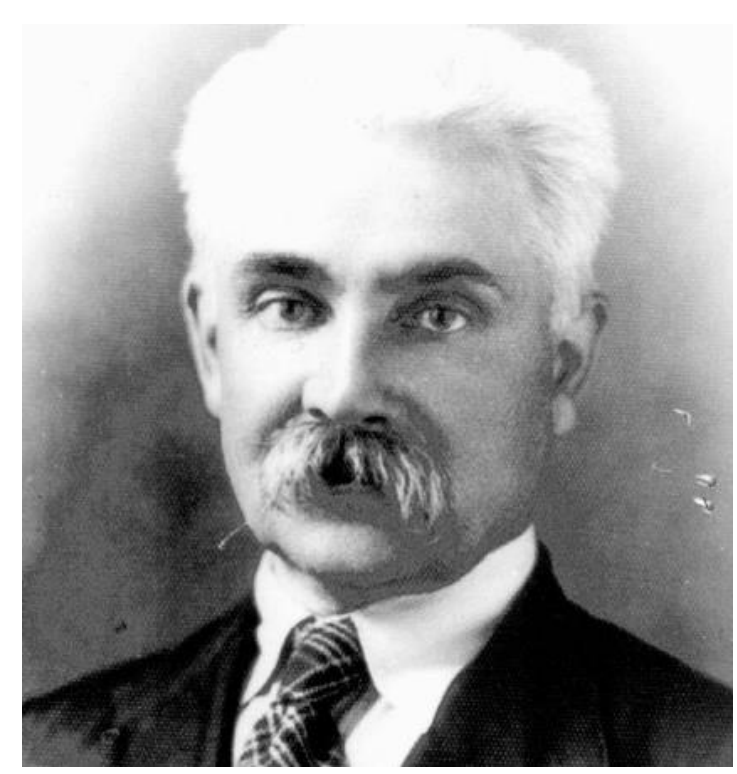

Рис. 2

участь і в організації Катеринославського університету. У курсі «Історії видавничої справи» студенти, зокрема, знайомляться з важливою історичною віхою - здійсненим I. Трубою виданням «Початкова читанка. Стежка додому», що відіграло важливу роль у становленні національної шкільної освіти.

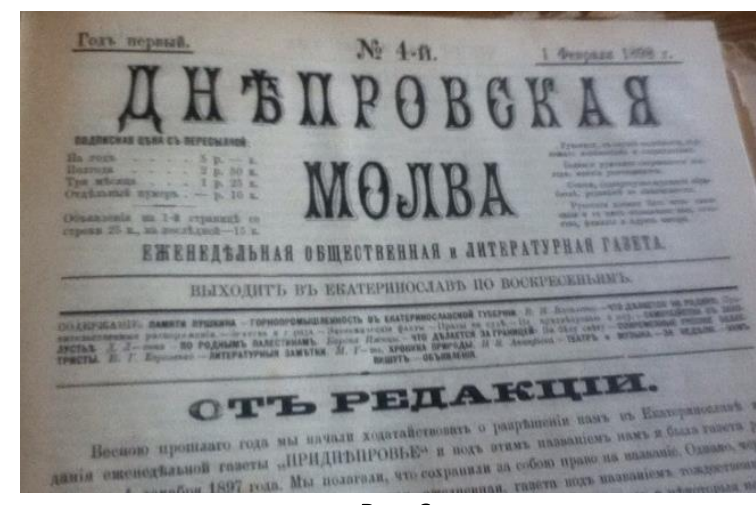

Рис. 3

Рубрика під літерою “Д» налічує 10 статей: «Двуглавый Орел», «Днепровская Молва» (див. рис. 3), «Днепровская правда», «Дніпрові хвилі», «Добра Порада», «Дорошенко Дмитро Іванович» (див. рис. 4),

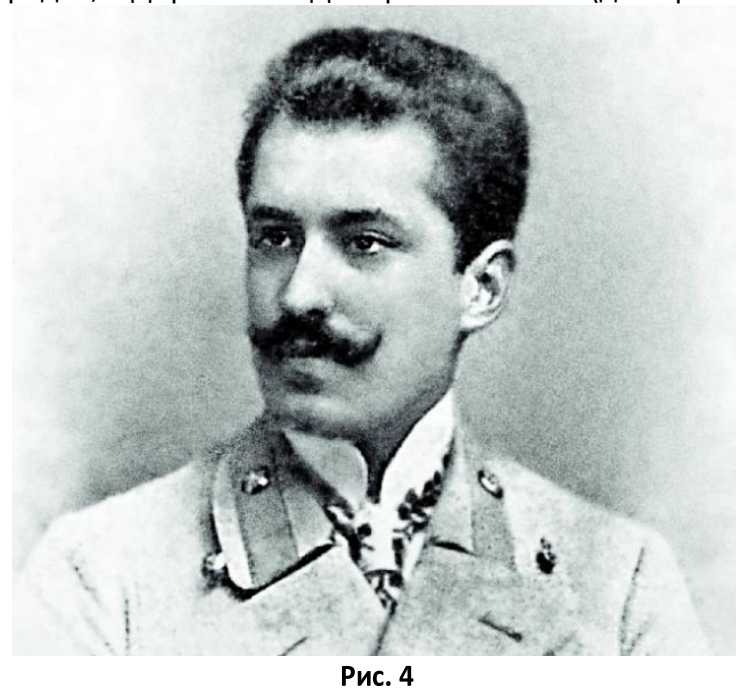


«Друкарня Барановського», «Друкарня Копилова (“М. С. Копыловъ”)», "Друкарня Потьомкіна», «Друкарня С. П. Яковлєва». Як бачимо, в даному разі більшу увагу приділено друкарням і конкретним виданням, а не діячам культурного руху. Деякі видання, приміром тижневики «Двуглавый Орел», «Днепровская Молва», часопис "Добра Порада», видавалися протягом всього кількох років, а газета «Днепровская правда» виходила з 1938 по 2011 р., тобто понад 70 років.

Щодо функціонування у Катеринославі друкарень, то у даній рубриці згадуються і відомі, скажімо, друкарня Барановського, в якій у 1906 р. видрукувано статут товариства «Просвіта», друкарня купця-мецената М. С. Копилова, який був одним з ініціаторів заснув ання в Катеринославі вищих жіночих курсів, що у 1918 р. стали основою створення університету (тепер Дніпровський національний університет імені Олеся Гончара, який у минулому році відзначив свій 100-річний ювілей), легендарна Потьомкінська друкарня та деякі менш відомі, але для формування панорамного уявлення про історію видавничої справи в нашому регіоні не менш значущі.

\section{4. Висновок}

Розглянувши особливості організації навчальної практики та підведення їі підсумків на тлі перебігу загального освітнього процесу, ми дійшли висновків про те, що наполегливі пошуки шляхів урізноманітнення форм проведення не лише самостійної роботи студентів, а й навчальної практики, суттєво сприятимуть її осучасненню та стимулюватимуть зацікавленість студентів специфікою майбутньої професії.

У ході соціологічного опитування студентів 2-4 курсів (тобто вікові характеристики респондентів - 18-20 років) було з'ясовано, що бібліографічний словник-довідник виявився цікавим для всіх без винятку студентів. Аудиторія опитуваних становила 124 особи. Серед запропонованих питань були, зокрема, такі: «Чи вважаєте ви можливим застосування подібних видань в освітньому процесі?», «Чи вважаєте ви задовільною якість презентованого видання?», «Чи є достатнім, на вашу думку, наповнення довідника?» Викладачі кафедри відчули задоволення від того, що 45 студентів виявили бажання особисто взяти участь у створенні подібних навчальних книжок. Такі результати, безумовно, надихають на пошуки нових сучасних форм роботи зі студентами, які наближали б майбутніх спеціалістів до таїн і конкретики обраної професії.

Здійснене за участю викладачів і студентів видання, про яке йшлося вище, може слугувати певним орієнтиром для колег з інших національних закладів вищої освіти і стати приводом для широкої наукової дискусії та обміну думками про запровадження та використання нетрадиційних, новаторських форм навчально-методичної та наукової роботи українського студентства.

\section{Список бібліографічних посилань}

1. Дубасенюк О. Упровадження освітніх інновацій в системі вищої освіти: проблеми, досвід, перспективи : монографія. Житомир : Вид-во ЖДУ ім. І. Франка, 2011. 444 с.
2. Musselin C. Change or Continuity in Higher Education Governance? Bleiklie I., Henkel M. (eds.) Governing Knowledge. Higher Education Dynamics. Vol 9. Dordrecht: Springer, 2005. P. 6579. doi: 10.1007/1-4020-3504-7_5.

3. Вітвицька С. Основи педагогіки вищої школи : підручник за модульно-рейтинговою системою навчання для студентів магістратури. Київ : Центр навчальної літератури, 2006. 384 с.

4. Положення про організацію навчального процесу в кредитно-модульній системі підготовки фахівців / укл. М. В. АфанасьєВ, В. С. Пономаренко. Харків : Вид. ХНЕУ, 2008. $244 \mathrm{c}$.

5. Кузьминський А. Педагогіка вищої школи : навчальний посібник. Київ : Знання, 2005. 486 с.

6. Schulze-Cleven, T. \& Olson, J.R. (2017) Worlds of higher education transformed: toward varieties of academic capitalism. Higher Education. 2017. Vol. 73. Issue 6. P. 813-831. doi: 10.1007/s10734-017-0123-3.

7. Нагаєв В. Методика викладання у вищій школі : навч. посібник. Київ : Центр учбової літератури, 2007. 232 с.

8. Ніколаєнко С. Якість вищої освіти в Україні: погляд у майбутнє. Світ фінансів. 2006. № 3(8). С.7-22.

9. Ортинський В. Педагогіка вищої школи : навч. посібник. Київ : Центр учбової літератури, 2007. 472 с.

10. Доценко К. Практика у професійному становленні студентів факультету журналістики : навчально-методичний посібник для денного і заочного відділень факультету журналістики (спеціальність «Журналістика»). Запоріжжя : ЗНУ, 2012.64 c.

11. Coleman, J. How to get published in English: Advice from the outgoing Editor-in-Chief. System. 2014. Vol. 42. P. 404-411. doi: 10.1016/j.system.2014.01.004.

12. Marsh L. The econometrics of higher education: editor's view. Journal of Econometrics. 2004. Vol. 121. Issues 1-2. P. 1-18. doi: 10.1016/j.jeconom.2003.10.007.

13. Women in Higher Education: The fight for equity. Edited by M. Meyers with D. Rios. Hampton University Press, 2012. 267 p.

14. Franssen, T., Kuipers, G. Coping with uncertainty, abundance and strife: Decision-making processes of Dutch acquisition editors in the global market for translations. Poetics. 2013. Vol. 41. Issue 1. P. 48-74. doi: 10.1016/j.poetic.2012.11.001.

15. How to Get Published in the Best Marketing Journals Edited by David W. Stewart and Daniel M. Ladik. Cheltenham (UK): Edward Elgar Publishing Ltd, 2019. 256 p.

16. Terry A. Continuing Education in the Scholarly Continuum: Back to School with Publishers, Librarians, and Vendors. Serials Review. 2001. Vol. 27. Issues 3-4. P. 62-78. doi: 10.1016/S00987913(01)00144-7.

17. Теорія і методика викладання в вищій школі. Конспект лекцій з навчальної дисципліни. Укл. Казак І.О. Київ : КПІ ім. Ігоря Сікорського, 2018. 116 с.

18. Каплинський В. Методика викладання у вищій школі. Вінниця : ТОВ «Ніланд лтД», 2015. 224 с.

19. Платонов К.К. Структура и развитие личности. Москва : Наука, 1986. 255 с.

20. Видавнича справа Придніпров'я в іменах: історія та сучасність. Укл. Куценко Л.В., Терханова О.В. Дніпро : ПВЦ «Адверта», 2018. 136 с.

21. Мильчин А. Культура издания, или Как не надо делать книги: Практич. руководство. Москва : Логос, 2002. 223 с.

22. Сава В. Основи техніки творення книги. Львів : Каменяр, 2000. $136 \mathrm{c}$.

23. Тимошик М. Книга для автора, редактора, видавця. Київ : Наша культура і наука, 2006. 560 с.

24. Видавнича справа в Україні : 1991-1996 : держ. бібліогр. покажчик / уклад. О. О. Федотова. Київ : Кн. палата, 1996. 32 с. 


\section{References}

1. Dubaseniuk, O. (2011) Implementation of educational innovations in the higher education system: problems, experience, prospects: monograph. Zhytomyr: Publisher of Zhytomyr Ivan Franko State University.

2. Musselin, C. (2005) "Change or Continuity in Higher Education Governance?” In: Bleiklie I., Henkel M. (eds.) Governing Knowledge. Higher Education Dynamics, 9, pp. 65-79. Dordrecht: Springer. doi: 10.1007/1-4020-3504-7_5.

3. Vitvitska, S. (2006) Fundamentals of higher education pedagogy: a textbook on the modular-rating system of education for master's students. Kyiv: Center for Educational Literature.

4. Afanasiev, V., Ponomarenko, M. (eds.) (2008) Regulations on the organization of the educational process in the credit-modular system of training specialists. Kharkiv: Simon Kuznets Kharkiv National University of Economics.

5. Kuzminsky, A. (2005) Pedagogy of the Higher School: a Textbook. Kyiv: Knowledge.

6. Schulze-Cleven, T. \& Olson, J.R. (2017) "Worlds of higher education transformed: toward varieties of academic capitalism", Higher Education, 73 (6), pp. 813-831. doi: 10.1007/s10734-0170123-3.

7. Nagayev, V. (2007) Teaching Methods in Higher Education: a Textbook. Kyiv: Center for Educational Literature.

8. Nikolaenko, S. (2006) "The quality of higher education in Ukraine: a look into the future", The World of Finance, 3 (8), pp. 7-22.

9. Ortinsky, V. (2007) Pedagogics of higher education: a Textbook. Kyiv: Center for Educational Literature.

10. Dotsenko, K. (2012) Practice in the Professional Formation of Students of the Faculty of Journalism: A Study Guide for the Fulltime and Part-time Departments of the Faculty of Journalism (specialty "Journalism"). Zaporozhye: Zaporizhzhya National University.
11. Coleman, J. (2014) “How to get published in English: Advice from the outgoing Editor-in-Chief", System, 42, pp. 404-411. doi: 10.1016/j.system.2014.01.004.

12. Marsh, L. (2004) "The econometrics of higher education: editor's view. Journal of Econometrics. 121 (1-2), pp. 1-18. doi: 10.1016/j.jeconom.2003.10.007.

13. Meyers, M., Rios, D. (eds.) (2012) Women in Higher Education: The fight for equity. Hampton University Press.

14. Franssen, T., Kuipers, G. (2013) "Coping with uncertainty, abundance and strife: Decision-making processes of Dutch acquisition editors in the global market for translations", Poetics, 41(1), pp. 48-74. doi: 10.1016/j.poetic.2012.11.001.

15. Stewart, D. W., Ladik, D. M. (2019) How to Get Published in the Best Marketing Journals. Cheltenham (UK): Edward Elgar Publishing Ltd.

16. Terry, A. (2001) "Continuing Education in the Scholarly Continuum: Back to School with Publishers, Librarians, and Vendors", Serials Review, 27 (3-4), pp. 62-78. doi: 10.1016/S00987913(01)00144-7.

17. Kazak, I. (ed.) (2018) Theory and Methods of Teaching in Higher Education. Kyiv: National Technical University of Ukraine "Igor Sikorsky Kyiv Polytechnic Institute".

18. Kaplinsky, V. (2015) Teaching Methods in Higher School. Vinnytsia: TOV «Niland LTD».

19. Platonov, K. (1986) Structure and development of personality. Moscow: Science.

20. Kutsenko, L., Terhanova O. (2018) Prydniprov'ya Publishing House in Names: History and Present. Dnipro: Adverta.

21. Milchin, A. (2002) Culture of the publication, or How not to do books: Practical. Moscow: Logos.

22. Sava, V. (2000) Fundamentals of the book creation technique. Lviv: Kamenyar.

23. Timoshik, M. (2006) Book for author, editor, publisher. Kyiv: Our culture and science.

24. Fedotova, O. (ed.) (1996) Publishing in Ukraine: 1991-1996: State Bibliography pointer. Kyiv: Book Chamber.

\section{Pidmohylna N., Terhanova 0 . The educational vectors in publishing and editing}

The article attempts to analyze the organization and the results of educational practice, which is an important component of the process of preparing future specialists in the field of publishing and editing, for students who are studying at the first (bachelor's) level of higher education. The European tendency of Ukrainian education provides not only reaching a single standard of educational programs, but also the proper professional training of specialists who could eventually realize the acquired knowledge and skills in any European country. Despite the existing differences in the technical equipment of publishing enterprises in Europe and in Ukraine, especially those located in the provinces, there is a certain set of knowledge and skills that will allow future specialists in the field of publishing to adapt to the latest printing equipment, to realize the acquired skills in further practical work. Teachers working at the Faculty of Systems and Media Communication at Oles Honchar Dnipro National University make considerable efforts to give students voluminous knowledge of both the history of social communications - not only within the Ukrainian paradigm, but also internationally - and about current trends in the development of the media, including all their forms and types. The teachers are also focused on such an important element of the educational process as student practice, defined as one of the forms or one of the teaching methods, focused not only on the acquisition of a certain amount of knowledge, but also on the acquisition of appropriate skills. It is the questions of the organization and the results of practical training of future specialists that we are trying to update in the proposed work. As an example of the implementation of educational and methodological searches in the organization of the educational process and the involvement of students in independent work in the field of publishing, its history and development in Ukraine, it was published a bibliographic dictionary "Publishing in Prydniprov'ya in Names: History and Modernity", compiled by the faculty together with the students, according to the results of training practice.

Usually, students gain knowledge on the history of publishing in university classes and from relevant university textbooks, but the content of the textbooks forms a general idea of the development of publishing houses and printing houses at different historical stages, and this knowledge remains in the theoretical foundation of the profession as information from special educational literature. It is completely different if students collect the materials on the history of publishing houses, publications and publishers related to the region in which they live. The personally collected and ordered information is firmly entrenched in the memory, and also significantly expands the idea of the cultural and historical processes, that took place in Prydniprov'ya - one of the Ukrainian cultural provinces.

Keywords: publishing and editing; studying proccess; educational practice; edition; independent work of students; "Publishing in Prydniprov'ya in Names: History and Modernity". 